Working Papers No. 110/08

\title{
The Economic History of Sovereignty: Communal Responsibility, the Extended Family, and the Firm
}

\author{
Lars Boerner \\ \& \\ Albrecht Ritsch
}

(C) Lars Boerner, Zurich

\& Albrecht Ritschl

London School of Economics 
Department of Economic History London School of Economics Houghton Street London, WC2A 2AE

Tel: $\quad$ +44 (0) 2079557860

Fax: $\quad$ +44 (0) 2079557730 


\title{
The Economic History of Sovereignty: Communal Responsibility, the Extended Family, and the Firm
}

Lars Boerner and Albrecht Ritschl

\begin{abstract}
Economic institutions encompassing increasingly sophisticated concepts of risk-sharing and liability flourished in Europe since the High Middle Ages. These innovations occurred in an environment of fragmented local jurisdictions, not within the framework of the territorial state. In this short paper we attempt to sketch a unifying approach towards the interpretation of the emergence of these institutions. We argue that communal responsibility in medieval city states created incentives for excessive risk-taking by individual merchants, and that the emergence of firms mitigated this problem. We also find that entity shielding in the sense of Hansmann et al. (2006) arose endogenously and is not primarily the result of regulation by local authorities.
\end{abstract}

\section{Introduction}

Medieval Europe is a surprising place. Mostly fragmented into myriads of micro territories and city states, it saw the spread of two major institutional innovations that one would have expected to originate within the perimeter of a well-organized territorial state. The first of these was a cashless pan-European payment system, the bill of exchange. The second was the emergence of the firm, a permanent business partnership. Both phenomena have attracted scholarly attention for over a century, with extensive research being conducted by the Younger Historical School (prominently, Max Weber, 1889; Goldschmidt, 1891). Research by legal and economic historians has since created a large literature, to the effect that the details of the underlying historical processes are well explored and a rich set of stylized facts is available. 
In the present paper we do not endeavour to add to the historical detail but rather attempt to establish a connection between the literatures on those two phenomena. We will argue that the principles that guided the first process - the emergence of bills of exchange as the dominant form of international payments in Europe - can also be found at the root of the second process - the emergence of business partnerships that went beyond the one-project, one-shot commenda contract. Greif (2004, 2006) has related the rise of the bill of exchange to the prevalence of the communal responsibility system in medieval Europe. Communal responsibility held all merchants of a town liable for each other in trade abroad. Similarly, it held all members of an extended family liable for each other vis-á-vis third parties. This archaic institution survived longer in the fragmented jurisdictions prevailing east of the Rhine and south of the Alps than in England and the nascent territorial states of Western Europe. We will argue in the following that communal responsibility is also at the root of explaining why the firm emerged first in the micro-territories of southern and Central Europe and not in the ascent territorial states.

Collective responsibility served to overcome agents' judgment proofness in the sense of Shavell (1986), the shielding from claims due to insufficient assets. At the individual level, collective responsibility widened the pool of seizable assets to the extended family (which under the definition prevalent in pre-modern times included also a merchant's employees). At the city level, communal responsibility widened the liability pool to all of its merchants travelling abroad, overcoming judgment proofness of merchants in transactions outside their city's local jurisdiction. However, both forms of collective responsibility had the character of a public good, as they gave agents access to wider liability pools without imposing insurance premia for risky activities and without providing proper monitoring. We argue that the emergent business partnerships were particularly well-suited to this environment, as they 
furnished an alternative solution to the judgment proof problem - first at the family level, later even at the city level - that provided for proper mutual monitoring and insurance of the business partners.

Our review of the literature corroborates this view. Legal historians studying town statutes found that lawmakers spent considerable effort on creditor protection, attempting to minimize judgment proofness of the nascent firms. In a parallel development, town statutes and courts progressively reduced collective liability of the extended family, thus effectively substituting a merchant's family with the firm as his main source of liability insurance. Indeed, there is a striking similarity, first noted probably by Max Weber (1889), between the concept of joint and several liability that became prevalent in business enterprises, and similar institutions known from family trusts since the Early Middle Ages.

We also find evidence on entity shielding, the protection of the firm from its stakeholders, whose historical significance has been emphasized by Hansmann et al. (2006). While entity shielding figured prominently in partnership contracts, we find little evidence of it in town statutes. In short, regulatory efforts in the city states of the Middle Ages centred strongly on creditor shielding, while entity shielding emerged endogenously with the business partnership, requiring little regulatory activity.

The rest of this brief paper is structured as follows. The next section elaborates on collective responsibility as a prime mover of the use of cashless means of payments, drawing on Greif $(2002,2006)$. We argue from our own earlier research (Boerner and Ritschl, 2002, 2006) that the basic parameters governing the setup discussed by Greif prevailed in much of Europe to the $17^{\text {th }}$ and even the $18^{\text {th }}$ century.

Section III reviews the debate on the origins of the firm - i.e., a long term business partnership. Scholars since Max Weber (1889) have noticed that business partnerships were rooted in contractual relationships within the family, and only gradually took on non-family 
members. In these family relationships, liability is the critical issue. Section IV looks at the debates about the evolution of the firm contracts, and argues that the liability concept governing the emerging firm is analogous to the one prevalent in community responsibility among merchants at the city level, which governs trade and payment relations across territories in much of medieval and early modern Europe.

These similarities appear to go beyond a mere analogy. In the concluding Section $\mathrm{V}$ we argue that both derive from the same historical root, mutual responsibility for the actions of family members, and that their coexistence, as well as their common decline in the $18^{\text {th }}$ century, must have systematic reasons and cannot be coincidental.

\section{Communal Responsibility and the Rise of Cashless Payments in Europe}

Trade and payments in medieval Europe advanced quickly despite considerable obstacles that presented themselves through the fragmentation of territorial sovereignty. Even in the absence of the benefits of a common legal framework and of unified law enforcement, credit relations and forward contracting blossomed since the $12^{\text {th }}$ and $13^{\text {th }}$ century (on the origin of the bill of exchange, see Goldschmidt, 1891; Schaps, 1892; Schaube, 1898; De Roover, 1953). Merchants' claims to future delivery of specie or goods were met almost universally abroad, and elaborate court proceedings were instituted everywhere in Europe to enforce contractual obligations in long distance trade and finance. With sovereignty as highly fragmented as in medieval Europe, this is surprising, as it made debts sovereign and hence shielded from enforcement. Sovereignty also implied that individual merchants would be shielded, or judgment proof (Shavell, 1986), from enforcement of claims 
from other jurisdictions than their own. The sovereign nature of this debt would largely prevent credit relations from developing.

Yet this is not what the historical evidence shows. Statutes and court proceedings from all over Europe that governed enforcement of these contracts have been analyzed extensively by scholars from the Historical School, see e.g. Wach (1868) or Planitz (1919). This research argued that communal liability among merchants of a given city was the relevant enforcement mechanism: merchants from a given city risked being arrested and have their goods confiscated when travelling through a jurisdiction where a fellow merchant from their hometown was in arrears on his payments. Even claims from third places seem to have been enforced in this way. This included debt enforcement by robber barons acting as the agents of frustrated creditors, see Volckart (2004). In practice, these rules implied that merchants in each city found themselves as members of a liability pool.

Greif $(2002,2004,2006)$ has argued that this system supported credit relations across cities even if the exchange among individuals from different cities was anonymous, provided only that their citizenship was known. Indeed, town statutes all over Europe stipulated that any unsettled claim would first have to be brought to court at the debtor's place of residence. Only if that court failed to enforce the payment could the case be brought before the court of the creditor's place of residence. The latter court's actions would then trigger retaliation against the debtor's city, which would range from arresting the next available merchant from that city to outright trade embargoes. Needless to say such cases occurred only as rare exceptions. City governments adhered to this procedure scrupulously, driven by the fear of losing attractiveness to foreigners as a market platform. Hence, most disputes were settled long before they were taken to the political level. 
The bill of exchange with its characteristic sequence of signatures and hence, ranking of liability - was almost automatically in compliance with this system, so long as two of the three or more parties were residents of different jurisdictions. If protested, the bill would be presented to the drawee's court first, to the drawer's court after that and so forth, depending on the chain of endorsements (which however were mostly a development of the $16^{\text {th }}$ and $17^{\text {th }}$ century). Beginning with the second stage, communal responsibility kicked in, giving the second court additional leverage to enforce payment from the drawee before the drawer's own liability (if from a different city) had to be invoked.

With these additional safeguards, bills of exchange were an instrument that allowed enforceability to travel across jurisdictions. In the early modern period, it became customary to hold annual clearing fairs where only bills of exchange were traded. These fairs would take place in Geneva, Lyon, or Genoa, clearing the claims arising from all over Europe against each other. Any remaining net claims would be rolled over to the coming year or be settled with bills drawn on the major banking places of Europe.

Boerner and Ritschl $(2002,2006)$ document how the autumn fairs of Frankfurt in Germany assumed a similar role for the German speaking countries, beginning in the $15^{\text {th }}$ century. Soon it became standard to make out bills of exchange payable in Frankfurt at the upcoming autumn fair, or to back local bills of different maturity with bills drawn on Frankfurt.

The salient point here is that these payment enforcement systems flourished in the absence of territorial unification. One reason, as has been documented by Thomas (1977) for the Champagne fairs, was that the expanding territorial states did more damage than good to commercial credit. Merchants preferred the relative safety of city republics and of the many small territories that competed with each other for offering the most attractive trade routes. In contrast, the sovereigns of large territories 
would seldom resist the temptation to sacrifice the long term benefits of flourishing trade to the short-term fiscal gains from extortion or outright expropriation (as was the case in France in the 1300s, which contributed to the demise of the champagne fairs).

A second reason why this payments system worked so well is precisely the myriad of local liability pools it created. Whether they liked it or not, merchants in a given city were tied into a scheme that insured foreign claimants, and that diverted the incentive problems for individual merchants away from foreign to domestic default. Much as it fostered long distance trade and payments, this system generated incentive problems at home, which had to be solved at home.

\section{Collective Liability Within the Family and the Rise of the Firm}

Scholarly research since Max Weber has agreed that the origins of the firm cannot be sought in either Roman law or the commenda contract of the Middle Ages. ${ }^{1}$ Roman law knew the societas, a contractual association. However, in contrast to the Italian compagnia that arose around the $12^{\text {th }}$ and became widespread during the $13^{\text {th }}$ century ${ }^{2}$, it lacked joint and several liability. Liability was not several, the Roman socii were liable only in proportion to their shares, pro rata parte. Liability was not joint either; the socii were liable only individually; a third party creditor would have to file claims against the member with whom he had actually contracted (Hacman, 1910).

The medieval business partnership was a major step ahead. Both general and limited partnerships were commonly used, and joint and several liability was the norm in the medieval Italian compagnia

\footnotetext{
${ }^{1}$ This was first stated by Max Weber (1889). For much additional evidence see Hacman (1910), as well as Sapori (1955b).

${ }^{2}$ See Roon-Bassermann (1912), Sapori (1955b), De Roover (1965), Blomquist (1971).
} 
contracts. ${ }^{3}$ The same pattern can be documented for South German firm contracts from the $14^{\text {th }}$ century onwards (Lutz, 1976, pp. 17-19; Thomas, 2003, pp. 41f), and later also in Baltic trade.(Cordes, 1998, pp.308-414).

Legal historians have long been puzzled by the emergence of this entity, which appeared to have only weak or no roots in Roman law. While collective responsibility was known at the city level, and was equally firmly rooted in the (extended) family, this institution appeared to be new. Max Weber (1889) dealt with this by arguing that the liability pool that characterized the firm emerged from earlier family trusts, which had their origins in Germanic tribal law.

Whatever the precise legal history of the institution, it is clear that most firms (even the giants emerging in Italy and, later, in Southern Germany) were essentially family firms that typically involved brothers, sons, cousins, and sons-in-law. Only gradually, non-family members from the same city were taken in. (Sapori, 1955a, pp. 803f.). Blomquist (1971, pp. 159f.) documents this for Lucca for the end of the $13^{\text {th }}$ century. In Southern Germany, partnerships transcending the family can hardly be found before the $15^{\text {th }}$ century. ${ }^{4}$

Partnership contracts among family members would provide for contingencies like the transfer of capital from the father to sons entering the firm, or the transfer of dowries to sons-in-law as capital shares (thus keeping the capital in the firm). In the same contractual frame, capital was bequeathed to the heirs of a senior partner after his death. Max Weber (1889) argued that this specific transaction constitutes the historical root of the business partnership contract. Indeed, the continued operation of an estate, a workshop, or a shop by the heirs was traditionally covered

\footnotetext{
${ }^{3}$ Typical setups are the Bonsignore contract from 1295 (Chiaudano, 1930, pp. 45-47) or a Peruzzi contract from 1324 (Sapori, 1934, p. 441; see also Hunt, 1994; Hunt and Murray, 1999).

${ }^{4}$ The few available business contracts and correspondence from the late $14^{\text {th }}$ and early $15^{\text {th }}$ century (Erlanger 1892; Lutz, 1976) include only family-members.
} 
under the instrument of manus communis. This institution, to be found in the codes of the Bavarians and the Langobards of the Early Middle Ages, did indeed stipulate joint and several liability among the heirs, which makes it a natural candidate for being the legal; source of the partnership contract.

But family liability went further than this in explaining the origins of the firm. Collective liability among family members in the High Middle Ages still included all members of a debtor's household. The concept was loosely defined and generously applied for the purpose of debt enforcement. Typically, it included the immediate family and the servants or employees. ${ }^{5}$ But it also included family members who were not physically living under the same roof with the debtor, but instead worked or pursued business interests together with him. In the extreme, a father would be liable for his son's business activities, even if those were unrelated to his own business. Family members and employees of a fugitive debtor could be arrested and imprisoned. Without written contracts, communal family responsibility and debt enforcement through collective punishment thus placed family and household members into a common liability pool (for detailed legal case studies on this see Hacman, 1910; Santarelli, 1964).

Collective responsibility among the extended family thus reduced judgment proofness and provided liability insurance to the individual merchant. On the other hand, collective family responsibility induced potentially severe agency problems. In the absence of formal contracts, informal liability insurance through the family would seldom, if ever, impose actuarily fair premia, thus potentially distorting merchants' choices of risky projects. Without proper monitoring, insurance through the family

\footnotetext{
${ }^{5}$ Greif (1996) argues that governing the agency relations between family and nonfamily members was actually a prime economic incentive in establishing the firm. In our framework, accepting a non-family partner to the firm would be analogous to adoption to the family.
} 
would induce suboptimal levels of care (for the relevant mechanisms see Shavell, 1986). Hence, while collective family responsibility was effective in reducing the exposure of creditors, it forced families into a liability pool with suboptimal characteristics.

The nascent firms provided alternative forms of liability insurance. These provided for tight mutual monitoring of the partners, were typically long-lived, and soon evolved into a collective entity that was more tightly knit than the extended families they replaced.

Most business partnerships were formally limited to a fixed term. Contracts often state durations of six to twelve years, and in rare cases no ending periods at all (Roon-Bassermann, 1912, p. 10; Lutz, 1976, pp. 210-213). This stands in contrast to other merchant partnership contracts, such as the commenda, which were venture-based (see Pryor, 1977, Boerner, 2007). The time limit on a business enterprise contract did not imply that the partnership would be dissolved after its termination. Instead, contracts were rewritten after the previous one had expired, often with minor changes to capital shares, the partners involved, etc. The contracts governing the Fugger company were regularly rewritten in sixyear intervals. What the time limit did imply was that a balance sheet would be drawn up at contract termination. In many cases, parties only left the compagnia in case of retirement or death. The exiting partners were replaced by new members. In this way, the compagnia could survive the life of its participants. Prominent examples of large and influential family firms include the company of the Bonsignori in Sienna during the $13^{\text {th }}$ (Roon-Bassermann, 1912, pp. 48-54), the Peruzzi of Florence during the $14^{\text {th }}$ (Sapori, 1955b, pp. 665-9), or the Fugger in Augsburg during the $16^{\text {th }}$ century (von Poelnitz, 1959).

These contracts went a long way towards entity shielding in the sense of Hansmann et al. (2006). Capital withdrawals before the expiry date were difficult or outright impossible. Partners had only access to 
capital in case of personal needs (Lutz, 1976, pp. 210, 370-82). Even in case of a partner's death, the heirs had only limited rights of access to the invested capital of their deceased relatives (ibid., pp. 412-14).

Tight contractual entity shielding and mutual monitoring among partners made it possible to present the compagnia to the outside world as a single entity, substituting the individual merchant with the collective of the partnership. Business agreements with third parties would typically include clauses such as in compagnia or et socii (Erlanger, 1892). Over time, business partnership contracts increasingly state a particular business name, typically the family name of the senior partner, which effectively became the firm's name. The obligation for partners to contract in the name of the compagnia was frequently stipulated in the partnership contracts. (Blomquist, 1971, p. 164; Lutz, 1976, pp.443-54). In this way, the businesses themselves became parties to the contract. Whether or not this contract included the particular individual depended on his status within the firm, not on his signature.

In addition to the active, fully liable partners, passive capital investors with limited liability were gradually admitted. These passive partners had no rights except an entitlement to a fixed return on their investment. Investments by these partners made a quantitatively important contribution to the firms' total capital. Passive investors often came from different cities. The Grosse Ravensburger Handelsgsellschaft in South Germany had passive shareholders from more than ten different cities during the $15^{\text {th }}$ century (Schulte, pp. 209f.). Documents available from the bankruptcy of the Zangmeister company of Memmingen paint a similar picture. (Westermann, 1908, pp.473).

In spite of their growing importance, legislation on the activities of these companies was rather limited. A rich supply of sources, including financial agreements with third parties, correspondence, bookkeeping, and internal contracts document the activities of these permanent 
business partnerships. This type of evidence is available from the second half of the $13^{\text {th }}$ century for Italy and from the late $14^{\text {th }}$ century for Germany. By comparison, legal records are much thinner. Towns mainly regulated the relation of company partners with third parties, but remained rather silent about business rules between partnership participants. If these were regulated at all, the statutes would not go beyond codifying standard business practice.

Town statutes thus typically attempted to keep judgment proofness of the company low. In the earliest statutes from $13^{\text {th }}$ and early $14^{\text {th }}$ century Italy, unlimited liability of all partners was the rule. (Hacmann, 1910, pp. 72-81; Roon-Bassermann, 1912, pp. 8f.). Liability remained mostly unregulated in German towns, until legislation from Nuremberg in 1479 adopted the standard Italian norms (Lutz, 1976, pp. 461-8). The same rules later spread into the Baltics (Thomas, 2003, pp. 91-5, 11533).

Courts were less sure about limited liability of passive investors. In a court case in Siena from 1344/5 between Pope Clemens VI. and the heirs of the Bonsignori company, a bank dissolved in 1289 , liability on outstanding debts was controversial. The heirs of small passive investors asked the town to limit their debts to their investments. However, the town of Siena rejected their request and confirmed unlimited liability of all partners (Roon-Bassermann, 1912, pp. 11-3). The context of this decision was earlier Sienese legislation that had relaxed joint liability in favour of pro rata liability. It has been argued that this development turned banking clients away from Siena (Sapori, 1955a, pp. 803-805). ${ }^{6}$ Thus, the court decision can be interpreted as an attempt to regain creditor confidence by strengthening liability again. For Germany, a law of 1464 under Emperor Frederick III removed this uncertainty and differentiated between limited

\footnotetext{
${ }^{6}$ This attempt remained isolated and gained no wider acceptance. (Sapori, ibid.)
} 
liability for passive investors and unlimited liability for active partners (Lutz, 1976, pp. 72-9).

The salient feature of this evidence is the absence of detailed legislation regarding the firm, or even of firm bankruptcy laws. Santarelli (1964, p. 186f.) emphasizes how surprising this fact is in the light of the many bankruptcy cases that can be documented only in Florence already during the $13^{\text {th }}$ century. Still, the Florentine code compilations of 1322 and 1415 make no mention of business bankruptcy. Santarelli concludes that the general principle of unlimited liability of business partners was sufficient to proceed in case of bankruptcy.

Hence, creditor protection, not entity shielding appears to have been the focus of legislative efforts, contrary to the assertion of Hansmann et al. (2006) that there was gradual evolution of entity shielding for companies in Medieval and Renaissance Italian bankruptcy law. Where city laws did mention the internal organization of business enterprises, they essentially codified common business practice. ${ }^{7}$

Entity shielding indeed figured prominently in firm contracts. Partners were restricted in or banned from conducting business outside of the firm, thus protecting the liability pool from any unmonitored activities. Capital withdrawals were restricted, and often additional contractual provisions were made to prevent partners from withdrawing when the partnership contract came up for renewal. To prevent buyouts by unwanted third parties, trade in shares was restricted or even ruled out.

Viewed in this perspective, the gradual evolution towards written partnership contracts is essentially a process of transferring unlimited liability from the extended family to a new artificial entity, the business partnership. This implied finding a new institution that solved the

\footnotetext{
${ }^{7}$ This is further corroborated by evidence from Germany, whose first bankruptcy law for firms (from Augsburg in 1574, see Hassler, 1928, pp. 52f.), makes no provisions for entity shielding.
} 
judgment proof problem of an individual merchant. At the same time, the nascent firm contributed to loosening the economic ties within the extended family, as it provided higher autarky values for individual members seeking liability insurance outside of the family.

With a firm contract at hand, the extended family could provide proof of existing business relationships within the family could to the authorities, as the legal presumption of a common household with the other partners in the family applied no longer. In the same vein, not being a partner to the business contract now became an effective shield against a relative's bankruptcy - while before, proof had to be brought that the commercial interests were separate, and that the relatives had not been living together for at least 10 years (Hacman, 1910). Finally, the firm contract now made it possible to document conditions of limited liability: a partner's exposure could now legally be limited to the capital share (or even less if the local laws permitted).

Thus, the firm emerged from the perimeter of the family and its archaic system of unlimited mutual liability. In the process of doing so, it internalized the externalities of family-wide liability insurance, which it replaced with contractual risk sharing and close mutual monitoring among the active partners. It codified the distinction between active and passive shareholders and limited the exposure of the latter. Collective liability within the extended family was thus replaced with joint and several liability within the company. As such, the firm gradually loosened its ties to the extended family, just as it further weakened the extended family itself. The interplay between the rise of corporations and the decline of the extended family in medieval Europe has been emphasized by Greif (2005). The shift from family responsibility to joint and several liability within the firm is but a special case of this wider phenomenon. These developments prepared the ground for the rise of a new entrepreneurial 
class that was autarkic from the communal liability structure of the family responsibility system.

\section{The Firm and Communal Responsibility at the City Level}

The nascent firm also impacted on a second liability pool, the communal responsibility of all merchants of a city in trade abroad. This institution provided liability insurance to a merchant's foreign clients. This had the potential to aggravate the judgment proof problem of the individual merchant, as it provided an incentive to engage excessively in risky activities, while transferring the risk from his clients abroad to his fellow merchants at home who were not parties to the contract. Arguably, the enterprise alleviated this problem, as it at least partly internalized this externality by forming liability pools that also provided internal monitoring.

One unresolved difficulty in this process was the emergence of firms that went beyond the city limits. While local firms were subject to local jurisdiction, conflicts could arise as soon as a firm's borders transcended the city limits. Indeed, Italian and German cities attempted to ban business partnerships of their citizens with foreigners.(Hacman, 1910, pp. 73f.; Lutz, 1976, pp.62-8). Such policies could be enforced visà-vis smaller companies. In the case of more powerful companies, a stopgap was to grant citizenship to the foreign partner, even if this entailed double citizenship. ${ }^{8}$ Clearly, city governments were worried about the risk of trade conflict arising over disputes within such international firms.

\footnotetext{
${ }^{8}$ Partnerships of members of different cities are regularly documented for Southern Germany from the second half of the 16th century onwards (see the company contracts in Lutz, 1976). A prominent exception was the Grosse Ravensburger Handelsgesellschaft, where we find members from three different cities already during the 15th century, see Schulte (1923).
} 
A prominent case from Nuremberg proved these worries to be correct (Lutz, 1976, pp. 141-53). A Nuremberg firm had admitted a partner (who was a relative of the other partners) from the city of Augsburg. Owing to the presence of the Fugger and Welser companies, Augsburg had considerable political influence, both regionally and internationally. A dispute soon broke out between the Augsburg and the Nuremberg partners of this business, leading to a long but inconclusive series of court decisions. The Nuremberg authorities were clearly interested in resolving the conflict outside of the courts and even used public money to try and settle parts of the disputed claims. Still, the case quickly gained political prominence and led to interventions by regional dukes as well as the city of Augsburg. In the end, the issue was presented to Emperor Frederick III, who actively intervened in the attempts to find a compromise. As a consequence, the city of Nuremberg saw its trade privileges seriously weakened, and the case is generally seen as having contributed to the rise of territorial jurisdiction. In addition, it accelerated the economic decline of the Reichsstaedte, Southern Germany's near-independent city republics that had controlled trade across the Alps and with Eastern Europe since the High Middle Ages.

The increasing economic clout of the enterprise also led to intensified political agitation against their increasing monopoly power.(Blaich, 1967; Lutz, 1976, pp. 79-123) The commercial activities and aspirations of South Germany's big firms were clearly global. During the $16^{\text {th }}$ century, the large Augsburg and Nuremberg firms were quite actively involved in expeditions and projects ranging from Latin America to South Asia. Upon the pressure of territorial sovereigns and most of the smaller cities, the German Reichstag in 1512 passed a monopoly act that provided for serious intervention against big firms, including even their forced breakup into smaller, non-monopolistic units. After intense political manoeuvring at the emperor's court, the act came up for a final decision 
at the Reichstag of 1521. However, proceedings at that meeting were seriously disrupted by an intense dispute that erupted over the antiVatican propaganda of a certain Martin Luther, who had been cited to appear at the emperor's court during the Reichstag to defend his views. As a result, discussion of the monopoly act was further adjourned but the issue dragged on. Finally, in 1530 the emperor's court decided to protect its fiscal interest and save German big business from breakup. Still, with this decision the dependency of large enterprises on the emperor had been cemented, exposing them to fiscal predation by the Habsburgs and eventually contributing to their decline.

\section{Concluding Remarks}

The family-based firm flourished better in those parts of Europe where fragmented jurisdictions prevailed and where communal responsibility remained the norm on foreign trade and payments. We believe this is not coincidental. Communal responsibility at the level of the merchant association established a local liability pool that resembled the ancient family responsibility system (and also had its roots there, see Boerner and Ritschl, 2002). Joint liability in the nascent firm was a similar concept, again with the same root, the liability within clans and extended families at the dawn of the Middle Ages. Both institutions originated from a tendency to channel this collective responsibility into civilized forms governed by due process, while retaining client protection against judgment proofness. Travelling merchants would be protected from random reprisals and outright robbery if a predictable system of sanctions was in place. Within the perimeter of the city, merchants would receive increased protection from sanctions against the extended family in case of insolvency and default. In both cases, we see a process at work in which mutual responsibility in the family is gradually limited and replaced 
with contractual institutions. In both cases, the institution opened itself gradually to non-family members. This had the effect of shifting the focus of protection against judgment proofness from the extended family to contractual organizations, of which the enterprise was better at internalizing the externalities of liability insurance. As the same time, it contributed to weakening the economic clout of the extended family .

Yet the connection between the two institutions was not just an evolutionary one. Communal responsibility at the city level gave merchants a strong incentive to form an association or guild, to control access and exit, and to monitor the behaviour of its members. Control is one reason why city authorities everywhere attempted to discourage business partnerships whose ownership transcended the city limits.

The externalities that arose with the communal responsibility system called for well defined risk sharing arrangements. The highly incomplete implicit contract that the old-style family responsibility system entailed was progressively substituted with business partnership contracts, initially still within the perimeters of the family. These far more explicit risk sharing contracts covered a wide range of contingencies, and alleviated many of the incentive problems if the older family responsibility system. This incentive to diversify risk and limit individual exposure of course always existed. Yet it was weaker in the open towns the nascent territorial states where both communal and family responsibility gave way to individual liability much earlier. Viewed this way, communal responsibility and the emergence of the firm in medieval Europe provided a case of institutional leapfrogging: both institutions were created to overcome the severe disadvantages that came with the persistence of the archaic institution of family liability and collective punishment. In the process, communal responsibility created and supported an ingenious system of collateralised international payments. The business partnership evolving out of communal responsibility created a system of risk sharing 
and of limiting liability to either the active partners or to the passive investment. This permitted the fast accumulation of large sums of entrepreneurial capital, long before the joint stock company was created. 


\section{References:}

Blaich, Fritz (1967), Die Reichsmonopolsgesetzgebung im Zeitalter Karls des V. Ihre ordnungspolitische Problematik, Stuttgart: Fischer.

Boerner, Lars (2007), Breaking Up Is Hard To Do: Partnership Dissolution and the Economics of the Medieval Commenda Contract, mimeo, Humboldt University of Berlin.

Boerner, Lars, Albrecht Ritschl, (2002), Individual Enforcement of Collective Liability in Pre-Modern Europe. Comments on Avner Greif, Journal of Institutional and Theoretical Economics 158, 205213.

Boerner, Lars, Albrecht Ritschl, (2006), Making Financial Markets: Medieval Communal Responsibility and the Coexistence of Money and Credit in a Monetary Matching Model, Paper presented at the Society of Economic Dynamics Conference, Vancouver.

Blomquist, Thomas (1971), Commercial Association in Thirteenth Century Lucca, Business History Review Vol. XLV, No. 2, 157-178.

Bonaini, Francesco (1854), Statuti inediti della città di Pisa dal XII al XIV secolo, Vol. 3, Florence: Vieusseux.

Chiaudano, Mario (1930), Studi e documenti per la storia del diritto commerciale italiano nel secolo XIII, Torino: Lattes.

Cordes, Albrecht (1998), Spätmittelalterlicher Gesellschaftshandel im Hanseraum, Cologne: Böhlau.

De Roover, Raymond (1953), L'évolution de la lettre de change. XIVEXVIII siècles, Paris: Librairie Armand Colin.

De Roover, Raymond (1965), The Organization of Trade, in: Cambridge Economic History, Vol. 3, 70-86. Cambdrige: Cambridge University Press.

De Roover, Raymond (1966), The Rise and Decline of the Medici Bank, 1397-1494, New York: Norton. 
Ehrenberg, Richard (1896), Das Zeitalter der Fugger, Vol. 1, Jena.

(Reprint 1963, Hildesheim: Olms).

Erlanger, Hugo (1892), Über Ursprung und Wesen der Firma, Esslingen:

Harburger'sche Buchdruckerei.

Goldschmidt, Levin, (1891),. Universalgeschichte des Handelsrechts,

Stuttgart: Enke

Greif, Avner (1996), The Study of Organizations and Evolving

Organizational Forms through History: Reflections from the Late

Medieval Family Firm, Industrial and Corporate Change, 5(2), 473-

501.

Greif, Avner, (2002), Institutional Foundations of Impersonal Exchange.

From Communal to Individual Responsibility in Pre-Modern Europe, Journal of Institutional and Theoretical Economics 158, 168-204.

Greif, Avner (2004), Impersonal Exchange without Impartial Law: The

Community Responsibility System, Chicago Journal of International Law 5, 109-138

Greif, Avner, (2005), Family Structure, Institutions, and Growth: The

Origins and Implications of Western Corporations, American

Economic Review, 96(2), 308-312.

Greif, Avner (2006), Institutions and the Path to Economic Modernity,

Cambridge: Cambridge University Press.

Hacman, Max (1910), Beitrag zur Entwicklung der offenen

Handelsgesellschaft, Beitrag zur Entwicklung der Offenen

Handelsgesellschaft, Zeitschrift für das gesamte Handelsrecht, vol. 68, 439-482; vol. 69, 47-92.

Hansmann, Henry, Reinier Kraakman, Richard, Squire, (2006), Law and the Rise of the Firm, Harvard Law Review, 119, 1333-1403.

Hassler, Friedrich (1928), Der Zusammenbruch der Augsburger

Handelsgesellschaft David Haug, Hans Langenauer und

Mitverwandte 1574-1606, Diss. TH Munich. 
Hunt, Edwin (1994), The Medieval Super-Companies, A Study of the Peruzzi Company of Florence, Cambridge: Cambridge University Press.

Hunt, Edwin, and James Murray (1999), A History of Business in Medieval Europe, 1200-1550, Cambridge: Cambridge University Press.

Lutz, Elmar (1976), Die rechtliche Struktur süddeutscher Handelsgesellschaften in der Zeit der Fugger, Vol. 1, Tübingen: Mohr.

Planitz, Hans (1919), Studien zur Geschichte des deutschen Arrestprozesses, Zeitschrift der Savigny-Stiftung für Rechtsgeschichte, Germanistische Abteilung, 40, 87-198.

Poelnitz, Goetz von, (1959), Die Fugger, Frankfurt: Scheffler. Postan, Michael (1957), Partnerships in English Medieval Commerce, in: Studi in Onore di Armando Sapori, Milan: Inst. Editoriale Cisalpino, 521-549.

Pryor, John (1977), The Origins of the Commenda Contract, Speculum 52, 5-37.

Roon-Bassermann, Else von (1912), Sienesische Handelsgesellschaften des 13. Jahrhunderts, Mannheim.

Santarelli, Umberto (1964), Per La Storia del Fallimento nelle Legislazioni Italiani dell'Eta Intermedia, Padova: CEDAM.

Sapori, Armando (1955a) Le compagnie mercantili toscane del dugento e dei primi del trecento: la responsibilita dei compagni verso i terzi, in: Studi di Storia Economica, Florence: Sansoni.

Sapori, Armando (1955b), Storia interna della compagnia mercantile dei Peruzzi, in: Studi di Storia Economica, Florence: Sansoni.

Schulte, Aloys (1923), Geschichte der Grossen Ravensburger Handelsgesellschaft, 1380-1530, Stuttgart: Deutsche VerlagsAnstalt. 
Schaps, Georg, (1892), Zur Geschichte des Wechselindossaments, Stuttgart: Enke.

Schaube, Adolf, (1898), Zur Geschichte und Natur des ältesten Cambium, Jahrbücher für Nationalökonomie und Statistik 70, 603621.

Shavell, Steven (1986), The Judgment Proof Problem, International Review of Law and Economics 6, 45-58.

Thomas, Frank (2003), Die persönliche Haftung von Gesellschaften von Personengesellschaften in der historischen Entwicklung der Neuzeit, Berlin: Duncker \& Humblot.

Thomas, Heinz (1977), Beiträge zur Geschichte der Champagne-Messen im 14. Jahrhundert, Vierteljahrschrift für Sozial- und Wirtschaftsgeschichte 64 (4), 433-467.

Volckart, Oliver (2004), The Economics of Feuding in Late Medieval Germany, Explorations in Economic History 41, 282-299,

Wach, Adolf, 1868. Der Arrestprozess in seiner geschichtlichen Entwicklung, Leipzig (Reprint 1973, Aalen: Scientia).

Weber, Max, 1889. Zur Geschichte der Handelsgesellschaften im Mittelalter nach südeuropäischen Quellen, Stuttgart: Enke.

Westermann, Askan, 1908. Die Zahlungseinstellung der Handelsgesellschaft der Gebrüder Zangmeister zu Memmingen 1566, in: Vierteljahrschrift für Sozial- und Wirtschaftsgeschichte 6, 460-516. 


\section{LONDON SCHOOL OF ECONOMICS}

\section{ECONOMIC HISTORY DEPARTMENT WORKING PAPERS}

(from 2003 onwards) For a full list of titles visit our webpage at

http://www.Ise.ac.uk/

\section{3}

WP70 The Decline and Fall of the European Film Industry: Sunk Costs, Market Size and Market Structure, 1890-1927 Gerben Bakker

WP71 The globalisation of codfish and wool: Spanish-English-North American triangular trade in the early modern period Regina Grafe

WP72 Piece rates and learning: understanding work and production in the New England textile industry a century ago Timothy Leunig

WP73 Workers and 'Subalterns'. A comparative study of labour in Africa, Asia and Latin America

Colin M. Lewis (editor)

WP74 Was the Bundesbank's credibility undermined during the process of German reunification?

Matthias Morys

WP75 Steam as a General Purpose Technology: A Growth Accounting Perspective

Nicholas F. R. Crafts

WP76 Fact or Fiction? Re-examination of Chinese Premodern

Population Statistics

Kent G. Deng

WP77 Autarkic Policy and Efficiency in Spanish Industrial Sector. An Estimation of the Domestic Resource Cost in 1958.

Elena Martínez Ruiz

WP78 The Post-War Rise of World Trade: Does the Bretton Woods System Deserve Credit?

Andrew G. Terborgh 
WP79 Quantifying the Contribution of Technological Change to Economic Growth in Different Eras: A Review of the Evidence Nicholas F. R. Crafts

WP80 Bureau Competition and Economic Policies in Nazi Germany, 1933-39

Oliver Volckart

2004

WP81 At the origins of increased productivity growth in services.

Productivity, social savings and the consumer surplus of the film industry, 1900-1938

Gerben Bakker

WP82 The Effects of the 1925 Portuguese Bank Note Crisis Henry Wigan

WP83 Trade, Convergence and Globalisation: the dynamics of change in the international income distribution, 1950-1998

Philip Epstein, Peter Howlett \& Max-Stephan Schulze

WP84 Reconstructing the Industrial Revolution: Analyses, Perceptions and Conceptions of Britain's Precocious Transition to Europe's First Industrial Society

Giorgio Riello \& Patrick K. O'Brien

WP85 The Canton of Berne as an Investor on the London Capital Market in the $18^{\text {th }}$ Century

Stefan Altorfer

WP86 News from London: Greek Government Bonds on the London Stock Exchange, 1914-1929

Olga Christodoulaki \& Jeremy Penzer

WP87 The World Economy in the 1990s: A Long Run Perspective Nicholas F.R. Crafts 
WP88 Labour Market Adjustment to Economic Downturns in the Catalan textile industry, 1880-1910. Did Employers Breach Implicit Contracts?

Jordi Domenech

WP89 Business Culture and Entrepreneurship in the Ionian Islands under British Rule, 1815-1864 Sakis Gekas

WP90 Ottoman State Finance: A Study of Fiscal Deficits and Internal Debt in 1859-63

Keiko Kiyotaki

WP91 Fiscal and Financial Preconditions for the Rise of British Naval Hegemony 1485-1815

Patrick Karl O'Brien

WP92 An Estimate of Imperial Austria's Gross Domestic Fixed Capital Stock, 1870-1913: Methods, Sources and Results Max-Stephan Schulze

2006

WP93 Harbingers of Dissolution? Grain Prices, Borders and Nationalism in the Hapsburg Economy before the First World War

Max-Stephan Schulze and Nikolaus Wolf

WP94 Rodney Hilton, Marxism and the Transition from Feudalism to Capitalism

S. R. Epstein

Forthcoming in C. Dyer, P. Cross, C. Wickham (eds.)

Rodney Hilton's Middle Ages, 400-1600 Cambridge UP 2007

WP95 Mercantilist Institutions for the Pursuit of Power with Profit. The Management of Britain's National Debt, 1756-1815 Patrick Karl O'Brien

WP96 Gresham on Horseback: The Monetary Roots of Spanish American Political Fragmentation in the Nineteenth Century Maria Alejandra Irigoin 
WP97 An Historical Analysis of the Expansion of Compulsory Schooling in Europe after the Second World War

Martina Viarengo

WP98 Universal Banking Failure? An Analysis of the Contrasting Responses of the Amsterdamsche Bank and the Rotterdamsche Bankvereeniging to the Dutch Financial Crisis of the $1920 \mathrm{~s}$ Christopher Louis Colvin

WP99 The Triumph and Denouement of the British Fiscal State: Taxation for the Wars against Revolutionary and Napoleonic France, 17931815.

Patrick Karl O’Brien

WP100 Origins of Catch-up Failure: Comparative Productivity Growth in the Hapsburg Empire, 1870-1910

Max-Stephan Schulze

WP101 Was Dick Whittington Taller Than Those He Left Behind?

Anthropometric Measures, Migration and the Quality of life in Early Nineteenth Century London

Jane Humphries and Tim Leunig

WP102 The Evolution of Entertainment Consumption and the Emergence of Cinema, 1890-1940

Gerben Bakker

WP103 Is Social Capital Persistent? Comparative Measurement in the Nineteenth and Twentieth Centuries

Marta Felis Rota

WP104 Structural Change and the Growth Contribution of Services: How Motion Pictures Industrialized US Spectator Entertainment Gerben Bakker

WP105 The Jesuits as Knowledge Brokers Between Europe and China (1582-1773): Shaping European Views of the Middle Kingdom Ashley E. Millar

WP106 Regional Income Dispersion and Market Potential in the Late Nineteenth Century Habsburg Empire Max-Stephan Schulze 
2008

WP107 'The Big Problem of the Petty Coins', and how it could be solved in the late Middle Ages

Oliver Volckart

WP108 The Anglo-German Industrial Productivity Puzzle, 1895-1935: A Restatement and a Possible Resolution Albrecht Ritschl

WP109 The History, Nature and Economic Significance of an Exceptional Fiscal State for the Growth of the British Economy, 1453-1815 Patrick O'Brien

WP110 The Economic History of Sovereignty: Communal Responsibility, the Extended Family, and the Firm

Lars Boerner and Albrecht Ritschl 